Bond University

Research Repository

\title{
AdaptSTAR model: A climate-friendly strategy to promote built environment sustainability
}

Conejos, Sheila; Langston, Craig; Smith, Jim

Published in:

Habitat International

DOI:

10.1016/j.habitatint.2011.12.003

\section{Licence:}

CC BY-NC-ND

Link to output in Bond University research repository.

Recommended citation(APA):

Conejos, S., Langston, C., \& Smith, J. (2013). AdaptSTAR model: A climate-friendly strategy to promote built environment sustainability. Habitat International, 37, 95-103. https://doi.org/10.1016/j.habitatint.2011.12.003

\footnotetext{
General rights

Copyright and moral rights for the publications made accessible in the public portal are retained by the authors and/or other copyright owners and it is a condition of accessing publications that users recognise and abide by the legal requirements associated with these rights.
}

For more information, or if you believe that this document breaches copyright, please contact the Bond University research repository coordinator. 


\title{
Bond University
}

\section{ePublications@bond}

$1-1-2012$

\section{AdaptSTAR model: A climate-friendly strategy to promote built environment sustainability}

\author{
Sheila Conejos \\ Bond University, Sheila_Conejos@bond.edu.au \\ Craig Langston \\ Bond University, craig_langston@bond.edu.au \\ Jim Smith \\ Bond University,jim_smith@bond.edu.au
}

Follow this and additional works at: http://epublications.bond.edu.au/sustainable_development Part of the Environmental Sciences Commons

\section{Recommended Citation}

Sheila Conejos, Craig Langston, and Jim Smith. (2012) "AdaptSTAR model: A climate-friendly strategy to promote built environment sustainability" Habitat international, 1-9: ISSN 0197-3975.

http://epublications.bond.edu.au/sustainable_development/93 


\title{
Adaptstar Model: A climate-friendly strategy to promote built environment sustainability
}

\author{
Sheila Conejos*, Dr. Craig Langston and Dr. Jim Smith \\ Institute of Sustainable Development and Architecture, Bond University, Gold Coast, QLD 4229, Australia \\ E-mail addresses: sconejos@bond.edu.au, clangsto@bond.edu.au, jismith@bond.edu.au
}

\begin{abstract}
Building adaptive reuse plays a critical role in emissions reduction and supports global climate protection. Thus, the designing of future buildings with embedded adaptive reuse potential is a useful criterion for sustainability. This paper describes the development of a new rating tool known as adaptSTAR, which offers holistic and unified design criteria suitable for assessing the adaptive reuse potential of future buildings. The findings show that criteria can be identified and weighted according to physical, economic, functional, technological, social, legal and political categories to calculate an adaptive reuse star rating. In addition, this paper reports on the first stage of the research methodology used in the initial development of the rating tool and concludes with some preliminary observations from twelve (12) selected successful case studies in New South Wales (NSW) and Melbourne, Australia. The use of adaptSTAR in designing future buildings will lead and help promote low carbon built environments.
\end{abstract}

Keywords: Adaptive Reuse, Sustainability, Built Environment, Climate Change, Architecture.

\section{Introduction}

The built environment is the world's largest user of energy, emitter of greenhouse gases and has the largest potential for efficiency (UNEP, 2009). According to Balaras et al. (2004), the existing stock has the greatest potential to lower the environmental load of the built environment significantly within the next 20 or 30 years. This imperative encourages building professionals to produce more energyefficient buildings and renovate existing stocks according to modern sustainability criteria (United Nations Environment Programme, 2007).

Building adaptive reuse is an alternative to traditional demolition and reconstruction; it is innately sustainable as it entails less energy and waste. It is defined as a significant change to an existing building function when the former function has become obsolete (Douglas, 2006). Adaptive reuse is relevant to the current climate change adaptation agenda due to its ability to recycle resources in place. Existing buildings that have been upgraded to achieve substantial cuts in greenhouse gas emissions (GGE) are considered a more climate-friendly strategy than producing new energy efficient buildings (TEC, 2008).

Adaptive reuse is a successful global strategy applied in many types of facilities around the world, including prestigious heritage buildings in most states in the United States, Australia and across the Asia Pacific region (Cantell, 2005; Langston et al., 2008; Department of Environment and Heritage, 2004; NSW Dept. of Planning, 2008; United Nations Educational Scientific and Cultural Organization, 2007). Moreover, building adaptive reuse has a major role to play in the sustainable development of communities, maintaining the social fabric whilst limiting potential demolition and reconstruction wastes (DEH, 2004). It also provides benefits of conserving green space, improving the micro-climate air quality, and maintaining habitat, ecosystem and water quality (Giles, 2005). This paper outlines the need for an adaptive reuse rating tool targeted to new design of buildings to support embedded adaptive reuse potential which will help promote built environment sustainability, and concludes on the initial development status of the adaptSTAR rating tool. 


\section{Literature Review}

\section{Adaptive Reuse, Sustainability and Sustainable Design Principles}

The Urban Land Institute (cited in Tobias and Vavaroutsos, 2009) indicates that new construction accounts for merely 1 to $1.5 \%$ of existing building stock each year in most developed countries. Naturally, the existing building stock represents the greatest opportunity for energy and carbon reduction. This is why adaptive reuse plays a critical role in reducing emissions from the built environment. UNEP (2009) emphasizes that adapting and retrofitting of existing buildings to the optimal energy efficiency standard must be given more focus by the building sector. Gorse and Highfield (2009) assert that there is no better example of the environmental benefits of effective sustainability in practice than the recycling of buildings. In addition, the Urban Land Institute (cited in Tobias and Vavaroutsos, 2009) report that green building practices have underemphasized the importance of sustainable retrofits of existing building stock globally and that environmentally sensitive and energy efficient sustainable new construction by itself cannot significantly change the environmental impact of the built environment unless green design and construction technologies are applied to the existing building stock.

However, there is still a lack of consensus as to what design criteria would best maximize the adaptive reuse potential of existing and future buildings. According to Kincaid (2000), important change in the use of buildings and infrastructure arises because of the development of certain technologies, thus it is important to know how to meet these new needs in existing buildings and how new buildings are designed to allow sustainable adaptability to occur in the future. For Zushi (2005), successful adaptive reuse projects require not only good design for the building, but also careful planning that considers its surrounding environment. As for Fournier and Zimnicki (2004), sustainable design principles that encourage maximum reuse of existing building components, restoration of passive aspects of the original design and preservation of the micro climate created by historic plantings and site usage should also be included in the adaptive reuse of historic buildings. Snyder (2005) examines the potential of adaptive reuse projects in sustainable design and integrates "green design" into structures that were previously at odds with natural processes. He also pointed out that adaptive reuse and sustainable design have a significant role in the future of architectural practice.

\section{Adaptive Reuse Potential (ARP) Model}

Until now experience and intuition are often the only guides to making decisions for adaptive reuse (Gorse and Highfield, 2009). However, through the ARP model (Langston et al., 2008) existing buildings can now be ranked on their adaptive reuse potential at any point in time. The ARP model is summarized in Figure 1 as firstly demonstrated by using a case study in Hong Kong (Langston and Shen, 2007).

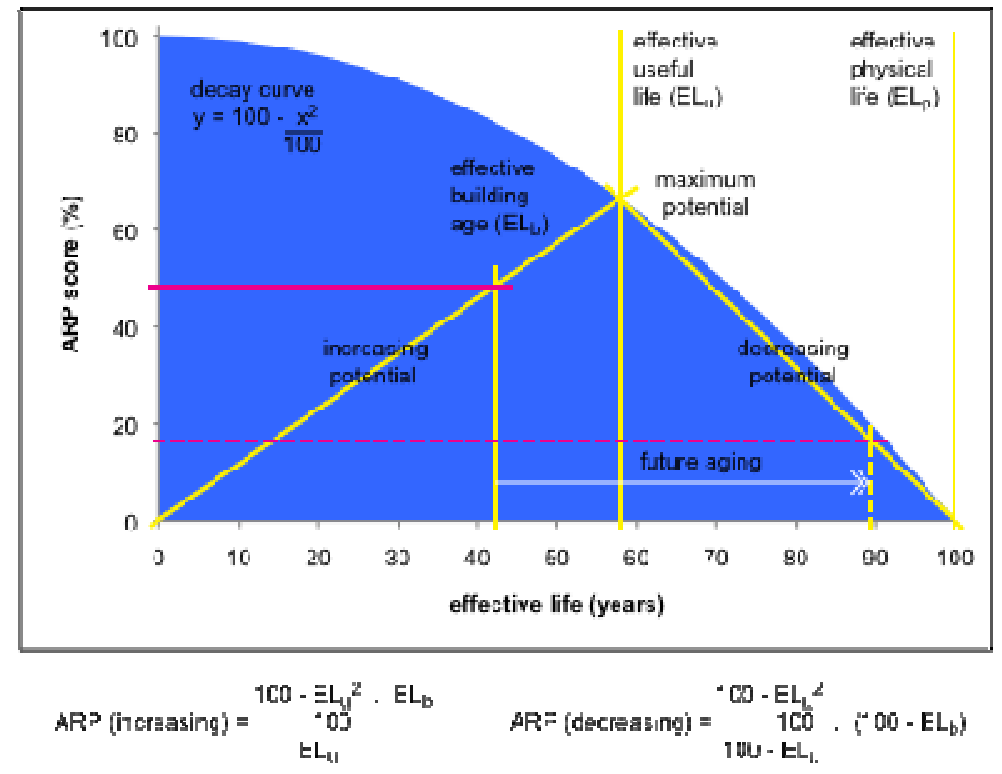

Fig. 1: Adaptive reuse potential model (Langston, 2008)

The useful (effective) life of a building or other asset in the past has been particularly difficult to forecast because of premature obsolescence (Seeley, 1983). The ARP model predicts useful life as a 
function of (discounted) physical life and obsolescence, and allows the calculation of the adaptive reuse potential at any point in a building's life cycle so that the right timing for intervention can be applied. The model has generic application to all countries and all building typologies. It requires an estimate of the expected physical life of the building and the current age of the building, both reported in years. It also requires an assessment of physical, economic, functional, technological, social, legal and political obsolescence, which is undertaken using surrogate estimation techniques as no direct market evidence exists. The ARP model has been widely published and is considered robust as it has been tested in hindsight against 64 adaptive reuse projects globally (Langston, 2008) and recently validated by a new multi criteria decision analysis tool called iconCUR (Langston, 2012).

\section{Research Methodology}

The aim of this research is to create and validate a design evaluation tool that will lead to making purposeful design decisions for future adaptive reuse at the time they are designed, or put simply, planning for reuse as a key design criterion. As a proven indicator for identifying the potential for adaptive reuse in existing building stock, this research will use Langston's ARP model to validate a new design rating tool called adaptSTAR, which is a weighted checklist of design strategies that lead to future successful adaptive reuse of buildings. The development and testing of this checklist is the focus for this research. The main deliverable of the research is the creation and validation of the new adaptSTAR model that will lead to best practice outcomes. It is similar in concept to the Green Building Council's Green Star or LEED methodology where performance is assessed using a standard five-star rating methodology.

This research is an explorative study and retrospectively analyzes existing successful adaptive reuse projects to establish a list of design factors (design criteria) that will be evaluated by members of the architectural profession. The methodological approach of this research is essentially in three stages and is a sequential mixed mode methodology (qualitative and quantitative). A combination of case study analysis, expert interview and practitioner survey is the approach selected to collect relevant data and enable the findings to be triangulated and validated. However, this paper reports on the results of the first stage of the research methodology since the other stages are in progress. Stage One is a qualitative approach that adopts a multiple case design to allow the researchers to fully understand the phenomenon of interest by using several independent case studies. A qualitative approach is most suitable for this type of exploratory research which encompasses theory building (Cresswell, 1998) and the use of evidence from multiple cases as they are deemed more compelling, which is essential to the overall study's robustness (Yin, 2009).

Stage One aims to identify an unweighted list of design criteria. Through the use of a qualitative approach, Australian practitioners involved in twelve successfully completed adaptive reuse case studies have been interviewed to solicit their views on key design criteria derived from analysis of their projects and underpinning literature. Fifteen key stakeholders who had expert case study knowledge were interviewed, and included representatives from the architectural team, developer, structural engineer, services engineer, quantity surveyor and facilities manager.

The twelve award-winning Australian adaptive reuse case studies are real life projects and demonstrate the successful blending of modern technology and design while respecting the building's historic character. They showcase rich and diverse architectural solutions in terms of conserving and adapting existing buildings to sustainable new uses. These selected case studies are adaptive reuse conversions throughout New South Wales, chosen among the over 20,000 heritage listed buildings in NSW because they represent different types of use and illustrate how the guidelines work in practice (NSW Department of Planning and RAIA, 2008). In addition, a pilot study of the GPO Melbourne was also conducted. The following successful adaptive reuse case studies are summarised in Table 1 and presented in a photo collage (see Fig. 2). 
Table 1: The Twelve (12) Selected Successful Adaptive Reuse Case Studies

\begin{tabular}{|c|c|}
\hline Case Study & Brief Description \\
\hline $\begin{array}{l}\text { 1. Small scale industrial } \\
\text { building converted to 4- } \\
\text { Unit Residential } \\
\text { Apartments, Egan } \\
\text { Street, Newtown, NSW. }\end{array}$ & $\begin{array}{l}\text { A small industrial warehouse was adapted to create three affordable } \\
\text { contemporary apartments and a studio office space for a collective of architects, } \\
\text { while retaining the heritage significance of the place. It is a representative } \\
\text { example of a } 1920 \text { s light industrial development and makes a positive aesthetic } \\
\text { contribution to the streetscape. It is located in the O'Connell Town Estate } \\
\text { Conservation Area. The project won the } 2006 \text { NSW Royal Australian Institute of } \\
\text { Architects ESD/Energy Efficiency Award, the Multiple Housing Award, the } \\
\text { President's Award and the } 2006 \text { National Trust Adaptive Re-Use Award. }\end{array}$ \\
\hline $\begin{array}{l}\text { 2. Conversion of the Grand } \\
\text { Babworth House to high- } \\
\text { end apartments in } \\
\text { Darling Point, NSW. }\end{array}$ & $\begin{array}{l}\text { A grand 93-room Sydney mansion called Babworth House was adapted to five } \\
\text { apartments, and ten new houses were constructed within its grounds. The house } \\
\text { and its garden setting are listed on the State Heritage Register. Designed in the } \\
\text { Federation Arts and Crafts style, the house displays an eclectic mix of Classical } \\
\text { Revival, Arts and Crafts and Art Nouveau styles. Magnificent oak-panelled walls, } \\
\text { decorative plaster work and an imposing timber stairway characterise the interior. } \\
\text { The Babworth House adaptation was the recipient of the Woollahra Conservation } \\
\text { Award in } 2004 \text { and was short-listed for the RAIA and National Trust } 2004 \text { awards. }\end{array}$ \\
\hline $\begin{array}{l}\text { 3. Rural agricultural } \\
\text { building into a tourist } \\
\text { information and function } \\
\text { centre in Tocal, NSW. }\end{array}$ & $\begin{array}{l}\text { The Tocal Visitor Centre was adapted from an early 20th century hay shed within } \\
\text { the State Heritage-listed Tocal Homestead precinct. It still maintains the } \\
\text { appearance and feel of an Australian rural shed. It provides a multi-purpose visitor } \\
\text { centre for both Tocal Homestead and Tocal Agricultural College. It is capable of } \\
\text { seating } 100 \text { guests, has a } 60 \text { seat theatrette and exhibition areas, and provides } \\
\text { modern and comfortable amenities for visitors. The converted shed won the } 2007 \\
\text { Ten Carat Award for Best Wedding Reception- Hunter Valley. }\end{array}$ \\
\hline $\begin{array}{l}\text { 4. Local church and church } \\
\text { hall into residential in } \\
\text { Glebe, NSW. }\end{array}$ & $\begin{array}{l}\text { A former church and church hall were adapted as two residences. The principal } \\
\text { elevations, roofs and overall forms of the buildings were retained and conserved. } \\
\text { The church and hall are located in the Toxteth Estate conservation area. The } \\
\text { streetscape of predominantly Victorian houses has a mixed residential character, } \\
\text { with single and two-storey terraces and some single dwellings. The conversion } \\
\text { was a finalist for the Greenway Award in the } 2007 \text { RAIA NSW Chapter Awards. }\end{array}$ \\
\hline $\begin{array}{l}\text { 5. Conversion of the } \\
\text { Bushells building, an } \\
\text { inner city industrial site } \\
\text { into offices in the Rocks, } \\
\text { Sydney, NSW. }\end{array}$ & $\begin{array}{l}\text { This former factory building was adapted to modern offices in a way that } \\
\text { preserves the structural clarity of the warehouse spaces, conserves and } \\
\text { incorporates a number of significant artefacts, and provides a rewarding and } \\
\text { unique work environment. The Bushells Building is a landmark within the historic } \\
\text { Rocks area of Sydney and is listed on the State Heritage Register. The building is } \\
\text { important because of its industrial character and its historical association with the } \\
\text { Bushells Company, once synonymous with Australia's cultural identity through } \\
\text { prolific and successful marketing campaigns over the last century. The project } \\
\text { was awarded the Master Builders Association Excellence in Construction Merit } \\
\text { Award for the Restoration or Renovation of an Historic Building and the UNESCO } \\
\text { Award for conservation and adaptation in } 2001 \text { and was highly commended for } \\
\text { both the Australian Property Institute Award for Best Development (heritage } \\
\text { refurbishment) and the Property Council of Australia Rider Hunt Award for } \\
\text { conservation and adaptation in } 2002 \text {. }\end{array}$ \\
\hline $\begin{array}{l}\text { 6. Defence buildings into } \\
\text { mixed use development } \\
\text { which include the } \\
\text { Sydney Harbour } \\
\text { Federation Trust Offices } \\
\text { in Georges Heights, } \\
\text { NSW. }\end{array}$ & $\begin{array}{l}\text { A group of former WWI hospital buildings was adapted by the Sydney Harbour } \\
\text { Federation Trust as part of an overall plan for a headland park extending from } \\
\text { Rawson Oval to Middle Head. Three former hospital buildings were converted into } \\
\text { a linked office space and headquarters for the Sydney Harbour Federation Trust. } \\
\text { The former hospital buildings are on the Commonwealth Heritage List. They sit on } \\
\text { a prominent knoll on the ridgeline, with excellent views to the east across Sydney } \\
\text { Harbour. Two of the buildings were part of a } 1915 \text { Army Auxiliary hospital and are } \\
\text { considered rare. All three buildings had been converted to other uses by the Army } \\
\text { over time. }\end{array}$ \\
\hline $\begin{array}{l}\text { 7. Commercial building into } \\
\text { art gallery in Broken Hill, } \\
\text { regional NSW. }\end{array}$ & $\begin{array}{l}\text { The Broken Hill Regional Art Gallery was adapted from a near ruinous former } \\
\text { mining hardware building in the main street of Broken Hill. The building now } \\
\text { exhibits the extraordinary art of the Broken Hill region, including contemporary art } \\
\text { and the local council collection, which dates from the council's establishment in } \\
\text { 1886. Interpretation was added to tell the history of the building and the story of } \\
\text { the development of Sully's Emporium as an important mining enterprise. It has } \\
\text { become a unique visitor experience, enhancing Broken Hill's appeal as a tourist } \\
\text { destination. Sully's Emporium is located within the Argent Street Conservation } \\
\text { Area and is included on the State Heritage Register. The conversion won the } \\
\text { Australian Property Institute Savills Heritage Award and the } \\
\text { Corporate/Government category of the Energy Australia, National Trust of } \\
\text { Australia (NSW) Heritage Conservation Award in the Built Heritage for projects } \\
\text { over } \$ 500,000 \text { category in } 2005 \text {. }\end{array}$ \\
\hline
\end{tabular}


Table 1: The Twelve (12) Selected Successful Adaptive Reuse Case Studies

\begin{tabular}{|c|c|}
\hline Case Study & Brief Description \\
\hline $\begin{array}{l}\text { 8. Conversion of the Mint } \\
\text { Coining Factory to the } \\
\text { Historic Houses Trust } \\
\text { head office and library in } \\
\text { Sydney, NSW. }\end{array}$ & $\begin{array}{l}\text { The surviving structures of the sandstone Coining Factory buildings of the Royal } \\
\text { Mint, Sydney (1855-1926) were adapted for use as the new head office of the } \\
\text { Historic Houses Trust (HHT). There are two structures on the Mint site - the Mint } \\
\text { offices on Macquarie Street (originally the south wing of Governor Macquarie's } \\
\text { General or 'Rum' Hospital, constructed from 1811-1816) and behind this, the } \\
\text { Coining Factory (constructed in } 1854 \text { for the Royal Mint). Located in the most } \\
\text { important civic precinct of Sydney, these buildings have a remarkable history of } \\
\text { use and adaptation over nearly } 200 \text { years. The Mint project received both the } \\
\text { Royal Australian Institute of Architecture's Sulman Award and the Greenway } \\
\text { Award in } 2004 \text {. At the time the judges commented that 'The whole ensemble is } \\
\text { given cohesion through carefully modulated scale and proportion, juxtapositions of } \\
\text { materials, light and shade, old and new, inside and out. A 19th century walled } \\
\text { factory has been transformed into a } 21 \text { st century campus. }\end{array}$ \\
\hline $\begin{array}{l}\text { 9. Railway workshops into } \\
\text { health and wellness } \\
\text { centre in Newcastle, } \\
\text { NSW. }\end{array}$ & $\begin{array}{l}\text { An historic railway workshop building was adapted for The Forum Health and } \\
\text { Wellness Centre, owned by University of Newcastle Sport. The building known as } \\
\text { Civic Railway Workshop Block A (the former Permanent Way Store or Perway } \\
\text { Building) is on the State Heritage Register. It is located between Workshop Place } \\
\text { and Harbour Square at Harbourside in Newcastle. It appears as a combination of } \\
\text { heritage railway and contemporary buildings within the Honeysuckle urban } \\
\text { regeneration area's contemporary streetscape. The project won the Babic } \\
\text { Construction Heritage Award and the Andrews Neil Peoples Choice Award in the } \\
2007 \text { RAIA Lower Hunter Urban Design Awards. }\end{array}$ \\
\hline $\begin{array}{l}\text { 10. Conversion of the } \\
\text { George Patterson } \\
\text { warehouse to a hotel } \\
\text { complex in Sydney, } \\
\text { NSW. }\end{array}$ & $\begin{array}{l}\text { Two buildings - substantially damaged by two simultaneous fires on } 2 \text { January } \\
1996 \text { - have been retained, conserved and adapted for a hospitality venue, } \\
\text { including a boutique hotel in the CBD. The building was adapted to accommodate } \\
\text { a series of bars and function spaces accessible from George Street, a boutique } \\
\text { hotel in the former warehouse section off Tank Stream Way, and a nightclub in } \\
\text { the lower ground and basement levels. The building was designed in the Queen } \\
\text { Anne Revival style and built between } 1892-1895 \text { for Holdsworth MacPherson \& } \\
\text { Co. hardware merchants and ironmongers, as a conjoined showroom and } \\
\text { warehouse with a water tower at the junction. At the time of its construction it was } \\
\text { considered the grandest emporium of its period. The project won an Interior } \\
\text { Architecture Award in the } 2001 \text { RAIA NSW Chapter Awards. }\end{array}$ \\
\hline $\begin{array}{l}\text { 11. Heritage-led urban } \\
\text { regeneration, } \\
\text { revitalisation of Prince } \\
\text { Henry Hospital, a } \\
\text { government health } \\
\text { facility into mixed use } \\
\text { development of } \\
\text { residential, commercial } \\
\text { and health facilities in } \\
\text { Little Bay, NSW. }\end{array}$ & $\begin{array}{l}\text { As recipient of numerous Australian awards for heritage and sustainability, the } \\
\text { Prince Henry redevelopment project contributes to a sustainable future by } \\
\text { providing a model for redevelopment of similar heritage and environmentally } \\
\text { sensitive areas in Australia. The Prince Henry site has been used by Aborigines } \\
\text { for thousands of years and was formerly a dilapidated hospital site for quarantine } \\
\text { of infectious diseases. The revitalization of the site balances the old and new } \\
\text { developments while keeping } 80 \% \text { of the site in public ownership. Over } 90 \% \text { of } \\
\text { demolition materials were reused and buildings comply with energy efficiency } \\
\text { principles while the whole redevelopment is based primarily on environmentally } \\
\text { sustainable design principles. The Prince Henry master plan starts with the } \\
\text { premise of conservation and enhancement. Its principles derive from analysis and } \\
\text { evaluation of the physical and cultural framework of the site and surrounding } \\
\text { environment. They address ecological sustainability, urban design, heritage, } \\
\text { amenity and accessibility. Noteworthy also to mention is that the Prince Henry } \\
\text { redevelopment won the President's Award from the Urban Development Institute } \\
\text { of Australia in } 2009 \text {, which was the highest accolade within the UDIA awards } \\
\text { program both state-wide and nationally. }\end{array}$ \\
\hline $\begin{array}{l}\text { 12. GPO Building, } \\
\text { Melbourne, Victoria } \\
\text { (Pilot Study) }\end{array}$ & $\begin{array}{l}\text { As one of the more prominent and well known adaptive reuse case studies in } \\
\text { Australia, Melbourne's GPO building has been awarded with the RAIA National } \\
\text { Award for Commercial Buildings and the Sir Osborn McCutcheon Commercial } \\
\text { Architecture Award. Melbourne's GPO was constructed on the Bourke and } \\
\text { Elizabeth Street corner site in } 1859 \text {. Between } 1859 \text { and } 1867 \text {, a much grander, } \\
\text { two-level building was developed and underwent a few major renovations until it } \\
\text { was completed in } 1919 \text { with its new sorting hall. In 1992, Australia Post } \\
\text { announced plans to sell the building and end the GPO's major postal role in } \\
\text { favour of decentralized mail centres. A shopping mall was proposed in } 1993 \text { but } \\
\text { its permit later lapsed, while in } 1997 \text { a hotel proposal did not proceed. Again in } \\
\text { early } 2001 \text { plans for a retail centre were announced but experienced a major } \\
\text { setback when the building was almost gutted by fire in September of that year. } \\
\text { Finally, the Melbourne's GPO building opened for trade as a retail centre in } \\
\text { October } 2004 \text {. As one of the CBD's premier boutique shopping destinations, the } \\
\text { GPO building houses over } 50 \text { stores across its three floors. }\end{array}$ \\
\hline
\end{tabular}

Sources: NSW Department of Planning and RAIA, 2008; Langston, 2008; Conejos, 2011 

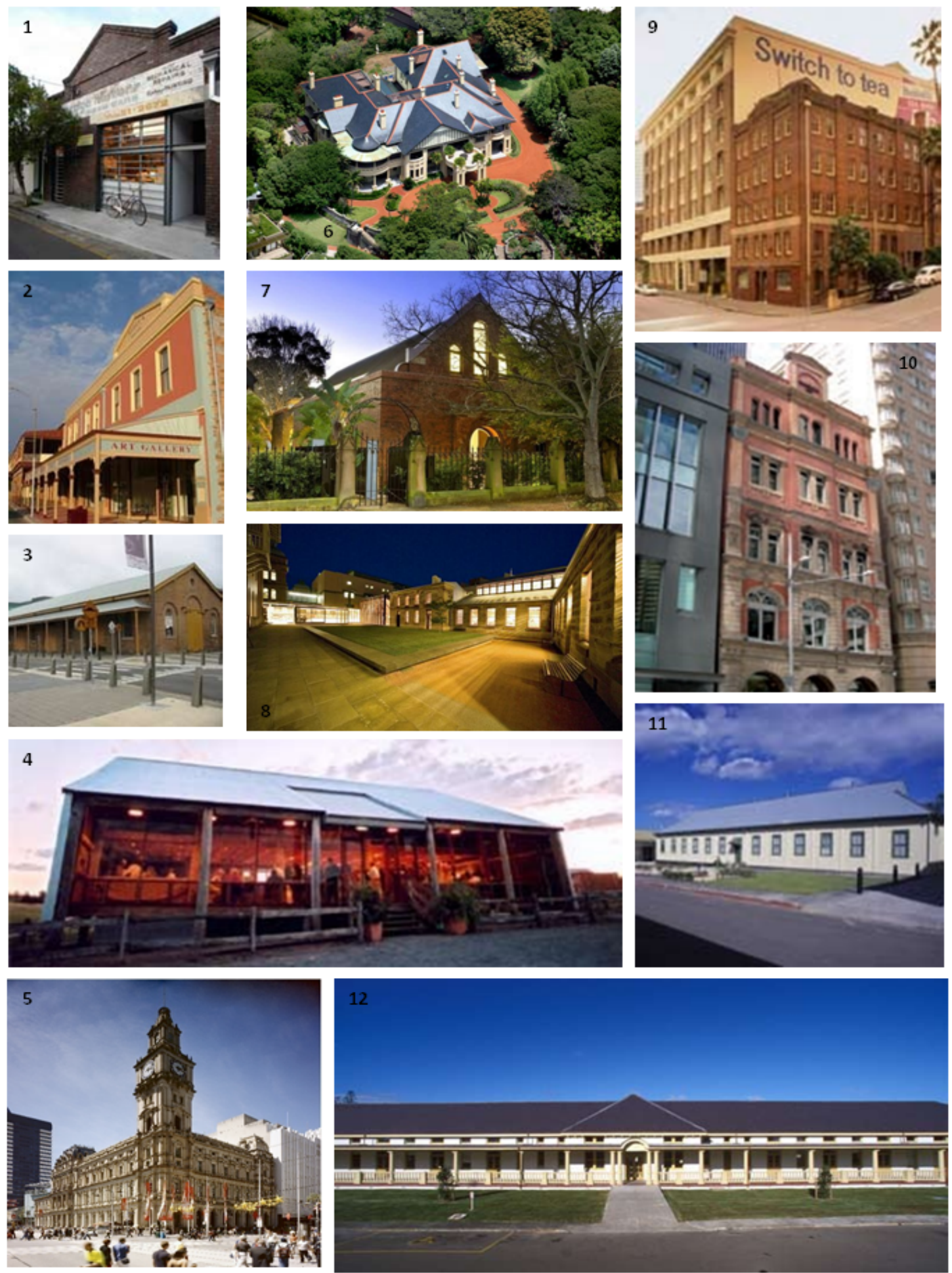

Legend: 1. Small scale industrial building converted to 4- Unit Residential Apartments, Egan Street, Newtown, NSW; 2. Commercial building into art gallery in Broken Hill, regional NSW; 3. Railway workshops into health and wellness centre in Newcastle, NSW; 4. Rural agricultural building into a tourist information and function centre in Tocal, NSW; 5 . GPO Building, Melbourne, Victoria (Pilot Study); 6. Conversion of the Grand Babworth House to high-end apartments in Darling Point, NSW; 7. Local church and church hall into residential in Glebe, NSW; 8. Conversion of the Mint Coining Factory to the Historic Houses Trust head office and library in Sydney, NSW; 9. Conversion of the Bushells Building, an inner city industrial site into offices in the Rocks, Sydney, NSW; 10. Conversion of the George Patterson warehouse to a hotel complex in Sydney, NSW; 11 . Defence buildings into mixed use development which include the Sydney Harbour Federation Trust Offices in Georges Heights, NSW; and 12. Heritage-led urban regeneration, revitalisation of Prince Henry Hospital, a government health facility into mixed use development of residential, commercial and health facilities in Little Bay, NSW.

Fig. 2: The 12 Selected Case Studies 
The case studies represent quite different building typologies. Given each case study will also have different latent characteristics; the list of factors is likely to be reasonably diverse. The assembly of these factors forms the base criteria to be used and scored in the adaptSTAR model. Factors will be collated into groups representing physical, economic, functional, technological, social, legal and political categories.

\section{Initial Development of the adaptSTAR Model}

The collected data in Stage One were transcribed, collated, managed and analyzed through the use of the NVivo software. NVivo (QSR, 2008) is qualitative research software that helps manage, shape and make sense of a researcher's data collection. With NVivo, analysis includes data classification, reduction, data display, theme identification and drawing of meaningful conclusions. Through the use of the case study protocol as a guide and the creation of nodes in NVivo, the Stage One case study analysis was organized and presented in two steps:

1. Construction of Each Case Study Profile: individual and in-depth case profiles based on comprehensive documentation (such as published literatures, approved building plans and maps, architect's conceptual schemes, news clippings and articles, and public reports) that were written about the twelve case studies; and

2. Addressing Research Objective: the pattern coding of key design criteria identified based on the in-depth expert interviews of the selected professionals involved in the case studies' design and construction implementation. This also includes the coding of key design criteria informed by the experts' interview results and relevant underpinning literature.

In identifying the list of factors, semi-structured interview questionnaires with the following themes were prepared:

1. History of the project: a brief background of the project from its existing use to its new adaptive use or building function; what major decisions/ events lead to its reuse; major considerations before undertaking the project; latent conditions;

2. Design and technical aspects: impediments encountered during the design process, how modern and green design features (if any) were incorporated or blended to the existing facilities; structural and utility challenges; legal and building code considerations;

3. Design process: design principles and criteria applied or implemented; design consultations conducted with stakeholders; adaptive reuse strategies identified or applied; critical factors that affected the success of adaptive reuse projects.

These discovered design criteria have been linked to the seven factors of obsolescence (physical, economic, functional, technological, social, legal and political) upon which the ARP model is based and illustrate that this connection is possible. The list of design criteria identified by the case study experts and linked to relevant literature on existing and recent design strategies that pertains to the adaptation of heritage buildings together with other building adaptation and sustainable design concepts/guidelines are presented below:

Table 2: List of Design Criteria (based on Experts' interviews and underpinning literature)

\begin{tabular}{|c|c|c|c|}
\hline Category & Criterion & $\begin{array}{c}\text { Experts } \\
(\mathrm{n}=15)\end{array}$ & Relevant Research Study \\
\hline \multirow[t]{7}{*}{$\begin{array}{l}\text { Long Life } \\
\text { (Physical) }\end{array}$} & $\begin{array}{l}\text { Structural Integrity- structural } \\
\text { design of the building to cater } \\
\text { future uses and loads }\end{array}$ & 8 & $\begin{array}{l}\text { Grammenos and Russell (1997); Russell and } \\
\text { Moffat (2001); Davison, et.al. (2006); } \\
\text { Osbourne (1985); Douglas (2006); Siddiqi } \\
\text { (2006); Horvath (2010); Gorse and Highfield } \\
\text { ( 2009); Yudelson (2010) }\end{array}$ \\
\hline & $\begin{array}{l}\text { Material Durability- durability of } \\
\text { the building asset }\end{array}$ & 8 & $\begin{array}{l}\text { Milne in UNEP (2007); Prowler (2008); } \\
\text { Osbourne (1985); Douglas (2006); }\end{array}$ \\
\hline & $\begin{array}{l}\text { Workmanship- quality of } \\
\text { craftsmanship of structure and } \\
\text { finishes }\end{array}$ & 7 & Osbourne (1985) \\
\hline & $\begin{array}{l}\text { Maintainability- building's } \\
\text { capability to conserve } \\
\text { operational resources }\end{array}$ & 5 & $\begin{array}{l}\text { Prowler (2008); Vakili-Ardebili (2007); } \\
\text { Osbourne (1985); Douglas (2006); Horvath } \\
\text { (2010) }\end{array}$ \\
\hline & $\begin{array}{l}\text { Design Complexity- various } \\
\text { geometries associated with the } \\
\text { building's design and innovation }\end{array}$ & 4 & $\begin{array}{l}\text { Grammenos and Russell (1997); Russell and } \\
\text { Moffat (2001); Browne (2006) }\end{array}$ \\
\hline & $\begin{array}{l}\text { Prevailing Climate- changing } \\
\text { climatic conditions }\end{array}$ & 2 & Wilson and Ward (2009); \\
\hline & $\begin{array}{l}\text { Foundation- differential } \\
\text { settlement and substrata } \\
\text { movement }\end{array}$ & 7 & Milne in UNEP (2007); Osbourne (1985) \\
\hline
\end{tabular}


Table 2: List of Design Criteria (based on Experts' interviews and underpinning literature)

\begin{tabular}{|c|c|c|c|}
\hline Category & Criterion & $\begin{array}{l}\text { Experts } \\
(\mathrm{n}=15)\end{array}$ & Relevant Research Study \\
\hline \multirow[t]{7}{*}{$\begin{array}{l}\text { Location } \\
\text { (Economic) }\end{array}$} & $\begin{array}{l}\text { Population Density- location } \\
\text { within major city, CBD, etc. }\end{array}$ & 2 & Langston et al. (2008); \\
\hline & $\begin{array}{l}\text { Market Proximity- distance to } \\
\text { major city, CBD, etc. }\end{array}$ & 3 & Campbell (1996); Fealy (2006) \\
\hline & $\begin{array}{l}\text { Transport Infrastructure- } \\
\text { availability and access }\end{array}$ & 3 & Prowler (2008); UNEP (2007); Heath (2001) \\
\hline & $\begin{array}{l}\text { Site Access-proximity or link to } \\
\text { access roads, parking and } \\
\text { communal facilities, etc. }\end{array}$ & 2 & Prowler (2008); UNEP (2007); Heath (2001) \\
\hline & Exposure-views, privacy & 2 & $\begin{array}{l}\text { Campbell (1996); Fealy (2006); Browne } \\
(2006)\end{array}$ \\
\hline & $\begin{array}{l}\text { Planning Constraints-site } \\
\text { selection, planning, } \\
\text { neighbourhood and building } \\
\text { design, etc. }\end{array}$ & 4 & Langston et al. (2008); \\
\hline & $\begin{array}{l}\text { Plot Size- built area, spatial } \\
\text { proportions, enclosure, etc. }\end{array}$ & 2 & Campbell (1996); Heath (2001) \\
\hline \multirow[t]{7}{*}{$\begin{array}{l}\text { Loose Fit } \\
\text { (Functional) }\end{array}$} & $\begin{array}{l}\text { Flexibility-space capability to } \\
\text { change according to newly } \\
\text { required needs, plug and play } \\
\text { elements, etc. }\end{array}$ & 12 & $\begin{array}{l}\text { Russell and Moffat (2001); Arge (2005); } \\
\text { Graham (2005); Prowler (2008); Vakjli- } \\
\text { Ardebili (2007); Douglas (2006); Horvath } \\
\text { (2010); Langston et al.(2008); Milne in } \\
\text { UNEP (2007); Nakib (2010); }\end{array}$ \\
\hline & $\begin{array}{l}\text { Disassembly-options for reuse, } \\
\text { recycle, demountable systems, } \\
\text { modularity, etc. }\end{array}$ & 4 & $\begin{array}{l}\text { Russell and. Moffat (2001); Graham (2005); } \\
\text { Vakili-Ardebili (2007) }\end{array}$ \\
\hline & $\begin{array}{l}\text { Spatial flow-mobility, open plan, } \\
\text { fluid and continuous }\end{array}$ & 5 & $\begin{array}{l}\text { Davison, et.al. (2006); Zeiler et al. (2010); } \\
\text { Horvath (2010) }\end{array}$ \\
\hline & $\begin{array}{l}\text { Convertibility-divisibility, } \\
\text { elasticity, multi-functionality }\end{array}$ & 5 & Russell and Moffat (2001); \\
\hline & $\begin{array}{l}\text { Atria- open areas, interior } \\
\text { gardens, etc. }\end{array}$ & 5 & Whimster (2008) \\
\hline & $\begin{array}{l}\text { Structural Grid- ideal and } \\
\text { economical limit of span and } \\
\text { fully interchangeable }\end{array}$ & 5 & $\begin{array}{l}\text { Grammenos and Russell (1997); Russell and } \\
\text { Moffat (2001); Arge (2005); Rabun and Kelso } \\
\text { (2009) }\end{array}$ \\
\hline & $\begin{array}{l}\text { Service Ducts and Corridors- } \\
\text { vertical circulation, service } \\
\text { elements, raised floors, etc.. }\end{array}$ & 11 & $\begin{array}{l}\text { Grammenos and Russell (1997); Russell and } \\
\text { Moffat (2001); Prowler (2008); Rabun and } \\
\text { Kelso (2009) }\end{array}$ \\
\hline \multirow[t]{7}{*}{$\begin{array}{l}\text { Low Energy } \\
\text { (Techno- } \\
\text { logical) }\end{array}$} & $\begin{array}{l}\text { Orientation-micro climate siting, } \\
\text { prevailing winds, sunlight, }\end{array}$ & 15 & $\begin{array}{l}\text { Prowler (2008); Douglas (2006); GBCA } \\
\text { (2010); Park (1998); UNEP (2007); Dittmark } \\
\text { (2008); Shaw et al. (2007) }\end{array}$ \\
\hline & $\begin{array}{l}\text { Glazing-sunlight glare control } \\
\text { and regulate internal } \\
\text { temperatures, etc. }\end{array}$ & 15 & $\begin{array}{l}\text { City of New York Department of Design and } \\
\text { Construction (1999); Douglas (2006); GBCA } \\
\text { (2010) }\end{array}$ \\
\hline & $\begin{array}{l}\text { Insulation and Shading- thermal } \\
\text { mass, sunshades, automated } \\
\text { blinds, etc. }\end{array}$ & 15 & $\begin{array}{l}\text { Osbourne(1985); Douglas (2006); GBCA } \\
\text { (2010); Klein (2008) }\end{array}$ \\
\hline & $\begin{array}{l}\text { Natural Lighting-inclusion for } \\
\text { natural daylight, efficient lighting } \\
\text { systems, etc. }\end{array}$ & 15 & $\begin{array}{l}\text { Osbourne (1985); Douglas (2006); GBCA } \\
\text { (2010); Park (1998); Holborrow (2008); Shaw } \\
\text { et al. (2007); Davison et al. (2006) }\end{array}$ \\
\hline & $\begin{array}{l}\text { Natural Ventilation-optimise } \\
\text { airflow, quality fresh air, } \\
\text { increase ambient air intake, etc. }\end{array}$ & 15 & $\begin{array}{l}\text { City of New York Department of Design and } \\
\text { Construction (1999); Wilson and Ward } \\
\text { (2009); Osbourne (1985); Douglas (2006); } \\
\text { GBCA (2010) ; Park (1998); Holborrow } \\
\text { (2008); Shaw et al. (2007) }\end{array}$ \\
\hline & $\begin{array}{l}\text { Building Management Systems- } \\
\text { monitor and control building } \\
\text { operations and performance } \\
\text { systems }\end{array}$ & 3 & $\begin{array}{l}\text { Grammenos and Russell (1997); Russell and } \\
\text { Moffat (2001); Levine, M. et al (2007); } \\
\text { Prowler (2008); GBCA (2010); Langston and } \\
\text { Shen (2007) }\end{array}$ \\
\hline & $\begin{array}{l}\text { Solar Access-measures for } \\
\text { summer and winter sun }\end{array}$ & 15 & $\begin{array}{l}\text { City of New York Department of Design and } \\
\text { Construction (1999); Wilson and Ward } \\
\text { (2009); Douglas (2006); GBCA (2010); Park } \\
\text { (1998); Dittmark (2008); Shaw et al. (2007) }\end{array}$ \\
\hline
\end{tabular}


Table 2: List of Design Criteria (based on Experts' interviews and underpinning literature)

\begin{tabular}{|c|c|c|c|}
\hline Category & Criterion & $\begin{array}{l}\text { Experts } \\
(\mathrm{n}=15)\end{array}$ & Relevant Research Study \\
\hline \multirow[t]{4}{*}{$\begin{array}{l}\text { Sense of } \\
\text { Place } \\
\text { (Social) }\end{array}$} & $\begin{array}{l}\text { Image/ Identity- social and } \\
\text { cultural attributes, values, etc. }\end{array}$ & 4 & $\begin{array}{l}\text { NSW Department of Planning (2008); Bond } \\
\text { and Charlemagne (2009); DEH (2004); Curry } \\
\text { (1995); Harmon et al.(2006); ICOMOS } \\
\text { (1994); Jokilehto (1996); Marquis-Kyle and } \\
\text { Walker (1994); UNESCO ( } 2007 \text { and 2009); } \\
\text { Fournier and Zimnicki (2004) }\end{array}$ \\
\hline & $\begin{array}{l}\text { Aesthetics-architectural beauty, } \\
\text { good appearance, proportion, } \\
\text { etc. }\end{array}$ & 4 & Prowler (2008); Farrel (2010); GBCA (2010) \\
\hline & $\begin{array}{l}\text { Landscape/ Townscape-visual } \\
\text { coherence and organization of } \\
\text { the built environment }\end{array}$ & 3 & $\begin{array}{l}\text { Davison, et.al. (2006); NSW Department of } \\
\text { Planning (2008); Fournier and Zimnicki } \\
\text { (2004); Zushi (2005); Shaw et al. (2007) }\end{array}$ \\
\hline & $\begin{array}{l}\text { History/ Authenticity-original } \\
\text { fabric, timelessness, socio- } \\
\text { cultural traditions, practices, } \\
\text { historic character or fabric, etc. }\end{array}$ & 4 & $\begin{array}{l}\text { Prowler (2008); NSW Department of } \\
\text { Planning (2008); Bond and Charlemagne } \\
\text { (2009); DEH (2004); Curry (1995); Harmon } \\
\text { et al.(2006); ICOMOS (1994); Jokilehto } \\
\text { (1996); Marquis-Kyle and Walker (1994); } \\
\text { UNESCO ( 2007 and 2009); Fournier and } \\
\text { Zimnicki (2004) }\end{array}$ \\
\hline \multirow{3}{*}{$\begin{array}{l}\text { Sense of } \\
\text { Place } \\
\text { (Social) }\end{array}$} & $\begin{array}{l}\text { Amenity-provides comfort and } \\
\text { convenience facilities }\end{array}$ & 2 & Browne (2006); Zushi (2005); Fealy (2006) \\
\hline & $\begin{array}{l}\text { Human Scale- anthropometrics } \\
\text { and fit to average human scale }\end{array}$ & 2 & $\begin{array}{l}\text { Campbell (1996); Grammenos and Russell } \\
\text { (1997); Russell and S. Moffat (2001); }\end{array}$ \\
\hline & $\begin{array}{l}\text { Neighbourhood-local and social } \\
\text { communities }\end{array}$ & 2 & HMSO (1987); DEH (2004); Browne (2006) \\
\hline \multirow{9}{*}{$\begin{array}{l}\text { Quality } \\
\text { Standard } \\
\text { (Legal) }\end{array}$} & $\begin{array}{l}\text { Standard of Finish-provision for } \\
\text { high standard workmanship }\end{array}$ & 9 & $\begin{array}{l}\text { Holborrow (2008); Park (1998); Osbourne } \\
\text { (1985) }\end{array}$ \\
\hline & $\begin{array}{l}\text { Fire Protection- provisions for } \\
\text { fire safety }\end{array}$ & 6 & $\begin{array}{l}\text { Davison, et.al. (2006); NSW Department of } \\
\text { Planning (2008); Douglas (2006); }\end{array}$ \\
\hline & $\begin{array}{l}\text { Indoor Environmental Quality- } \\
\text { provisions for non-hazardous } \\
\text { materials, natural fabrics, etc. }\end{array}$ & 11 & $\begin{array}{l}\text { Prowler (2008); City of New York } \\
\text { Department of Design and Construction } \\
\text { (1999); }\end{array}$ \\
\hline & $\begin{array}{l}\text { Occupational Health and Safety- } \\
\text { special needs of occupants, } \\
\text { health and safety risks, building } \\
\text { hazard and risk management } \\
\text { plan }\end{array}$ & 2 & $\begin{array}{l}\text { Prowler (2008); NSW Department of } \\
\text { Planning (2008); City of New York } \\
\text { Department of Design and Construction } \\
\text { (1999); Douglas (2006); }\end{array}$ \\
\hline & $\begin{array}{l}\text { Security- provision of direct and } \\
\text { passive surveillance designs }\end{array}$ & 3 & $\begin{array}{l}\text { Prowler (2008); NSW Department of } \\
\text { Planning (2008); Osbourne (1985); Douglas } \\
\text { (2006); }\end{array}$ \\
\hline & $\begin{array}{l}\text { Comfort- hygiene and clean } \\
\text { environment, etc. }\end{array}$ & 2 & $\begin{array}{l}\text { Prowler (2008); Osbourne (1985); Gilder } \\
(2010)\end{array}$ \\
\hline & $\begin{array}{l}\text { Disability Access- provision for } \\
\text { disability easement, facilities, } \\
\text { etc. }\end{array}$ & 6 & $\begin{array}{l}\text { NSW Department of Planning (2008); } \\
\text { Douglas (2006); }\end{array}$ \\
\hline & $\begin{array}{l}\text { Energy Rating- environmental } \\
\text { performance measures }\end{array}$ & 3 & $\begin{array}{l}\text { NSW Department of Planning (2008); } \\
\text { Douglas } 2^{\text {nd }} \text { ed. (2006); }\end{array}$ \\
\hline & $\begin{array}{l}\text { Acoustics- noise control, sound } \\
\text { insulation, etc. }\end{array}$ & 8 & Osbourne (1985); Douglas (2006); \\
\hline \multirow[t]{4}{*}{$\begin{array}{l}\text { Context } \\
\text { (Political) }\end{array}$} & $\begin{array}{l}\text { Adjacent Buildings- adjacent } \\
\text { enclosures, vertical and visual } \\
\text { obstacles }\end{array}$ & 1 & Davison, et.al. (2006) \\
\hline & $\begin{array}{l}\text { Ecological Footprint- appropriate } \\
\text { measure of human carrying } \\
\text { capacity }\end{array}$ & 15 & $\begin{array}{l}\text { Cantell (2005); Tobias and Vavatrous (2009); } \\
\text { UNEP (2007); Langston and Shen (2007); } \\
\text { Giles (2005); Gilder (2010); Balaras et al. } \\
\text { (2004) }\end{array}$ \\
\hline & $\begin{array}{l}\text { Conservation- principles, } \\
\text { guidelines, charters governing } \\
\text { tangible and intangible heritage } \\
\text { protection }\end{array}$ & 8 & $\begin{array}{l}\text { Curry (1995); Harmon et al.(2006); ICOMOS } \\
\text { (1994); Jokilehto (1996); Marquis-Kyle and } \\
\text { Walker (1994); UNESCO ( } 2007 \text { and 2009); } \\
\text { Fournier and Zimnicki (2004) }\end{array}$ \\
\hline & $\begin{array}{l}\text { Community Interest/ } \\
\text { participation-Stakeholder } \\
\text { relationship and support }\end{array}$ & 12 & $\begin{array}{l}\text { Langston et al. (2008); HMSO (1987); } \\
\text { Browne (2006) }\end{array}$ \\
\hline
\end{tabular}


Table 2: List of Design Criteria (based on Experts' interviews and underpinning literature)

\begin{tabular}{|c|l|c|l|}
\hline Category & \multicolumn{1}{|c|}{ Criterion } & $\begin{array}{c}\text { Experts } \\
(\mathrm{n}=15)\end{array}$ & \multicolumn{1}{|c|}{ Relevant Research Study } \\
\hline & $\begin{array}{l}\text { Urban Masterplan- integrated } \\
\text { skyline, urban landscape, built } \\
\text { environment design and } \\
\text { management/ practice }\end{array}$ & 8 & $\begin{array}{l}\text { Wilson and Ward (2009; Douglas (2006); } \\
\text { Heath (2001) }\end{array}$ \\
\cline { 2 - 4 } & $\begin{array}{l}\text { Zoning- land uses and land } \\
\text { patterns }\end{array}$ & 7 & $\begin{array}{l}\text { City of New York Department of Design and } \\
\text { Construction (1999); Wilson and Ward } \\
\text { (2009); Douglas (2006);Campbell (1996); } \\
\text { Browne (2006) }\end{array}$ \\
\cline { 2 - 4 } & $\begin{array}{l}\text { Ownership- collaborative } \\
\text { commitment, sense of } \\
\text { community or ownership, etc. }\end{array}$ & 4 & HMSO (1987) \\
\hline
\end{tabular}

Sources: Table showing building adaptive reuse design criteria from relevant research study in Conejos et al., 2011 and updated with the expert interviews results in Conejos, 2011.

As the research progresses, the identified list of design criteria will be evaluated to determine the weighted value of its associated and corresponding design elements and this will be done in Stage Two of the research methodology. The set of design criteria reflect the obsolescence categories: Physical (Long Life); Economic (Location); Functional (Loose Fit); Technological (Low Energy); Social (Sense of Place); Legal (Quality Standard) and Political (Context). With regards to the outcome of Stage 1, the initial framework of the proposed adaptSTAR model is shown in Figure 3.

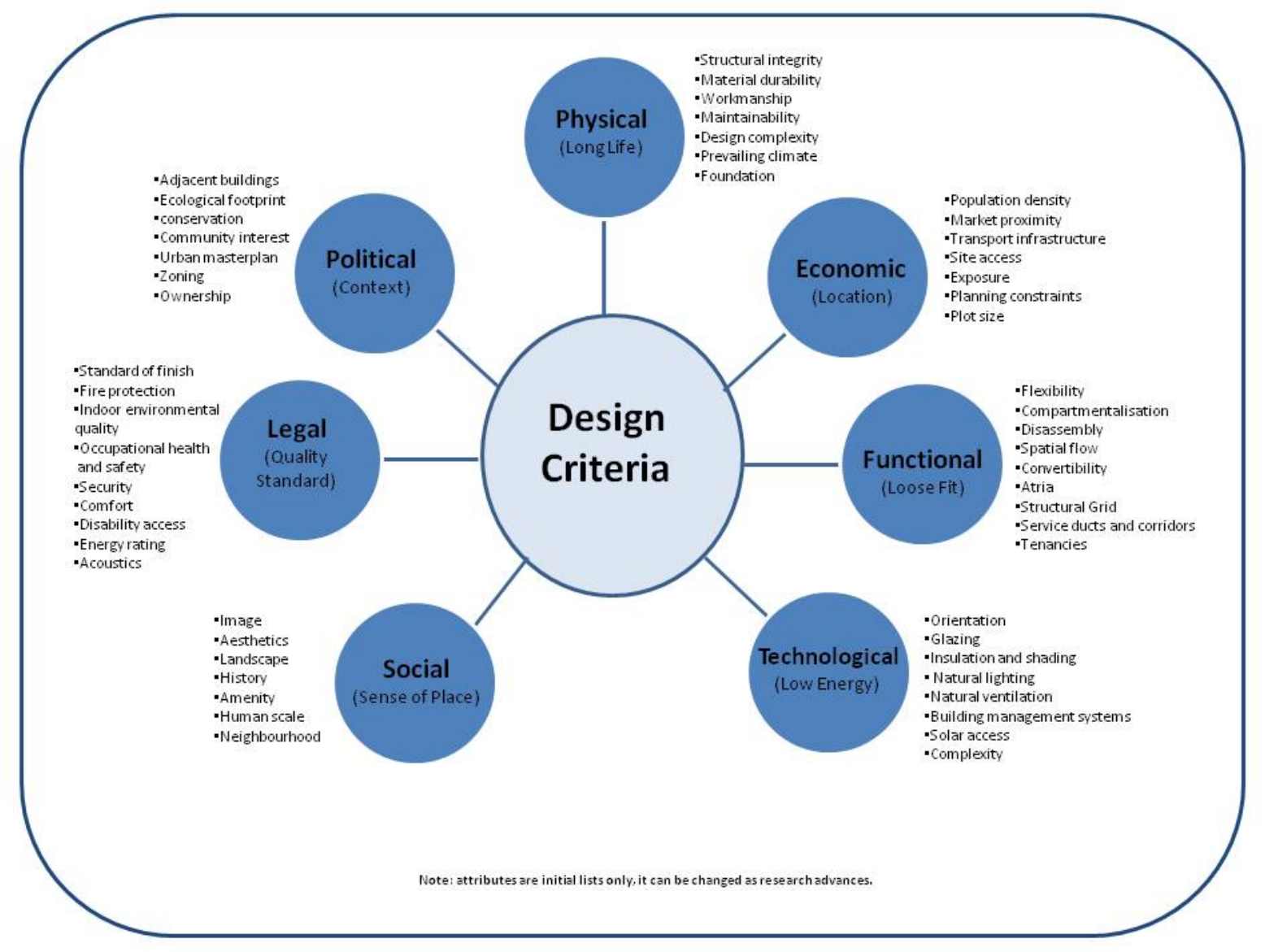

Fig. 3: Proposed adaptSTAR Model

\section{Conclusion and Further Research}

Amidst the diverse collection of design principles, strategies, approaches and solutions that have been in existence in the past, this research indicates a knowledge gap pertaining to the lack of clear design criteria for future adaptive reuse and the lack of consensus as to what design criteria would 
best maximize the adaptive reuse potential of future buildings. This is a new field and this knowledge gap is expected.

Moreover, this research gives insights on how building designers approach the design process, solve problems, make decisions and address the potential complexity and value conflict in undertaking building adaptive reuse projects. Hence, this work leads to a better understanding of how designers can best be assisted in these activities in order to increase the likelihood of achieving design solutions that offer better future building adaptive reuse opportunities during the conceptualization process. Thus, when designing new buildings it is important to be concerned about maximizing the adaptive reuse potential of buildings later in their lives to help mitigate the effects of a changing weather climate plus the volatility of social, economic and environmental conditions. So, it is imperative that designers should fully understand the context of the existing built environment and consider the needs of new buildings through appropriate design technologies.

With the completion of the Stage One of this research, a list of design criteria have been identified to support the designing of future building adaptive reuse. Based on the interviews of selected expert professionals, they are geared towards the technological or environmental, physical and functional design criteria. Although there is less support for the socio-cultural design criteria, it must be noted that all selected case studies are heritage buildings and successful landmarks in NSW and Victoria. It is anticipated that the list of design criteria will be critically assessed once Stage Two of this research takes place.

The final development of the new adaptSTAR design rating tool is underway. Stage Two of the research will use a quantitative research methodology wherein a concise structured survey conducted electronically (and anonymously) to registered architects in Australia is used to rank and weight the list of design criteria by assessing the relative importance of each strategy and their contexts while Stage Three is the testing of the new adaptSTAR model against Langston's (2008) ARP model. This research paper has initially identified important design criteria needed for the sustainability and future adaptive reuse of new buildings. The research methodology outlined in this study is expected to assist in the reliability and validity of the new design rating tool. The outcome of this research and the application of the adaptSTAR model will be useful in the practical applications of adaptive reuse of the existing built environment as well as incorporation of adaptive reuse strategies for future buildings and help promote the development of sustainable built environments.

\section{References}

Arge, K. (2005). Adaptable office buildings: theory and practice. Journal of Facilities, 23(3/4), 119e127. Balaras, C. A., Dascalaki, E., \& Kontoyiannidis, S. (2004). Decision support software for sustainable building refurbishment. ASHRAE Transactions, 110, 592e601.

Bond, S., \& Charlemagne, D. W. (February 2009). Built cultural heritage and sustainability-the role of value based decisions.

Browne, L. A. (2006). Regenerate: Reusing a landmark building to economically bolster urban revitalization, Master thesis, University of Cincinnati.

Campbell, J. (1996). Is your building a candidate for adaptive reuse? Journal of Property Management, $6(1)$.

Cantell, S. F. (2005). The adaptive reuse of historic industrial buildings: Regulation barrier, best practices and case studies. In The adaptive reuse of historic industrial buildings: Regulation barrier, best practices and case studies. Master Thesis: Virginia Polytechnic Institute and State University, USA. 40.

City of New York Department of Design and Construction. (1999). High performance building guidelines. USA, City of New York: NYCDDC.

Conejos, S. (2011). In depth personal interview with the case study expert respondents. In In depth personal interview with the case study expert respondents. Sydney, Canberra, Melbourne.

Conejos, S., Langston, C., \& Smith, J. (2011). Improving the implementation of adaptive reuse strategies for historic buildings. Aversa and Capri, Naples, Italy: La scuola di Pitagora s.r.l.

Creswell, J. (2009). Research design: Qualitative, quantitative, and mixed methods approaches. Sage Publications, Inc.

Curry, M. (1995). John Hunter and lan Ralston, Archaeological resource management in the UK: an Introduction. International Journal of Cultural Property, 4(1), 179e181, Alan Sutton Publishing, Institute of Field Archaeologists, Bath, 1993.

Davison, N., Gibb, A. G., Austin, S. A., Goodier, C. I., \& Wagner, P. (2006). The multispace adaptable building concept and its extension into mass customisation. paper presented to Adaptables2006, TU/e, International Conference on Adaptable Building Structures, Eindhoven, The Netherlands, July 2006. 
DEH. (2004), Adaptive reuse: Preserving our past, building our future. ACT: Department of Environment and Heritage, Commonwealth of Australia. 17.

Dittmark, H. (2008). Continuity and context in urbanism and architecture: honesty of a living tradition. Conservation Bulletin, Autumn(59), 7e9.

Douglas, J. (2006). Building adaptation. UK: Elsevier Ltd.

Farrell, A. (2010). Intelligent eco-physiological architecture: A primer for a sustainable built environment. paper presented to Building a Better World: CIB World Congress 2010, The Lowry, Salford Quays, United Kingdom.

Fealy, J. (2006). Adaptive reuse for multi-use facilities in an urban context: making the city home again, Master thesis, University of Cincinnati.

Fournier, D., \& Zimnicki, K. (2004). Integrating sustainable design principles into the adaptive reuse of historical properties. Washington DC: U.S. Army Corps of Engineers. 61.

GBCA. (2010). What is green star?. [Online], Available: http://www.gbca.org.au/ green-star/green-staroverview/ viewed February 192010.

Gilder, J. (2010). Bio inspired intelligent design for the future of buildings. Paper presented to Building a Better World: CIB World Congress 2010, The Lowry, Salford Quays, United Kingdom.

Giles, G. (2005). Adaptive reuse in an urban setting: evaluating the benefits of reusing an existing building site in Florida for maximum profit potential and eco-effectiveness. Environmental Design \& Construction, 72.

Gorse, G., \& Highfield, D. (2009). Refurbishment and upgrading of buildings. Spon Press.

Graham, P. (2005). Design for adaptability. In. BDP environment design guide, Vol. Gen 66 (pp. 1e9).

Grammenos, F., \& Russell, P. (1997). Building adaptability: a view from the future. paper presented to International Conference on Buildings and Environment, June 1997.

Harmon, D., Mcmanamon, F. P., \& Pitcaithley, D. T. (2006). The Antiquities Act: A century of American archaeology, historic preservation, and nature. Tucson, Arizona, USA: University of Arizona Press.

Heath, T. (2001). Adaptive reuse of offices of residential use. Cities, 18(3), 173e184. HMSO. (1987). Town and country planning (Use Classes) order 1987. London: HMSO.

Holborrow, W. (2008). Cutting down on carbon from the public sector estate. Conservation Bulletin, Spring(57), 26e29.

Horvath, T. (2010). Necessity of modernization of modern buildings. paper presented to Building a BetterWorld: CIBWorld Congress 2010, The Lowry, Salford Quays, United Kingdom.

ICOMOS. (1994). Convention for the protection of cultural property in the event of Armed conflict. [Online], Available: http://www.icomos.org/hague/viewed January 82010.

Jokilehto, J. (1996). A History of Architectural Conservation: The Contribution of English, French, German and Italian towards International Approach to the Conservation of Cultural Property, $\mathrm{PhD}$ Thesis thesis, Phd thesis, University of York, England.

Kincaid, D. (2000). Adaptability potentials for buildings and infrastructure in sustainable cities. Facilities, 18, 155e161.

Klein, T. (2008). Research in architectural engineering Series. Netherlands: Delft University Press.

Langston, C. (2008). The sustainability implications of building adaptive reuse (keynote paper). In The sustainability implications of building adaptive reuse, $1 \mathrm{e} 10$.

Langston, C. (2012). Validation of the adaptive reuse potential (ARP) model using iconCUR. Facilities, $30,193 \mathrm{e} 207$.

Langston, C., \& Shen, L. Y. (2007). Application of the adaptive reuse potential model in Hong Kong: a case study of Lui Seng Chun. The International Journal of Strategic Property Management, 11(4), $193 \mathrm{e} 207$.

Langston, C., Wong, F., Hui, E., \& Shen, L. Y. (2008). Strategic assessment of building adaptive reuse opportunities in Hong Kong. Building and Environment, 43(10), $1709 \mathrm{e} 1718$.

Levine, M., Urge-Vorsatz, D., Blok, K., Geng, L., Harvey, D., Lang, S., et al. (Eds.). (2007). Residential and commercial buildings. Vol. Fourth assessment report of the intergovernmental panel on climate change, climate change 2007: Mitigation. United Kingdom and New York, USA: Cambridge University Press.

Marquis-Kyle, P., \& Walker, M. (1994). The illustrated Burra Charter: making good decisions about the care of important places. Australia ICOMOS with the assistance of the Australian Heritage Commission, Sydney.

Nakib, F. (2010). Toward an adaptable architecture guidelines to integrate adaptability in building. paper presented to Building a Better World: CIB World Congress 2010, The Lowry, Salford Quays, United Kingdom.

NSW Department of Planning, \& RAIA, (2008). New uses for heritage places: Guidelines for the adaptation of historic buildings and sites. In New uses for heritage places: guidelines for the adaptation of historic buildings and sites. Sydney: Joint Publication of the Heritage Council of New SouthWales and the Royal Australian Institute of Architects. 
Osbourne, D. (1985). Introduction to building Mitchell's building series. London: Batsford Academic and Educational.

Park, S. C. (1998). Sustainable design and historic preservation. CRM, 2, $13 \mathrm{e} 16$.

Prowler, D. (2008). Whole building design guide. U.S.A: National Institute of Building Sciences.

QSR. (2008). Moving on in NVIVO 8: Exploring, visualizing and sharing your material. USA: QSR International, Pty Ltd.

Rabun, S., \& Kelso, R. (2009). Building evaluation for adaptive reuse and preservation. New Jersey: John Wiley and Sons, Inc.

Russell, P., \& Moffat, S. (2001). Adaptability of Buildings. November 2001.

Seeley, I. (1983). Building Economics: Appraisal and control of building design cost and efficiency. UK: Macmillian Press.

Shaw, R., Colley, M., \& Connell, R. (2007). Climate change adaptation by design: A guide for sustainable communities. London: TCPA.

Siddiqi, K. (2006). Benchmarking adaptive reuse: a case study of Georgia. Environmental Technology and Management, 6(3/4), 346e361.

Snyder, G. H. (2005). Sustainability through adaptive reuse: The conversion of industrial building. In Sustainability through adaptive reuse: The conversion of industrial building. Unpublished Master. University of Cincinnati.

TEC, (2008). Commercial property and climate change-exposures and opportunities existing building project. In Commercial property and climate changeexposures and opportunities existing building project. Australia: Total Environment Centre. p. 4.

Tobias, L., \& Vavaroutsos, G. (2009). Retrofitting office buildings to be green and energy-efficient: Optimizing building performance, tenant satisfaction and financial return. Urban Land Institute.

UNEP. (2007). Buildings and Climate Change Status, challenges and opportunities. UNEP Publications.

UNEP. (2009). Buildings and climate Change: Summary for decision-makers. UNEP publications.

UNESCO. (2007). Asia conserved: Lessons learned from the UNESCO Asia-Pacific heritage awards for culture heritage conservation (2004e2004). Bangkok: UNESCO.

UNESCO. (2009). Hoi An protocols for best conservation practice in Asia: Professional guidelines for assuring and preserving the authenticity of heritage sites in the context of the cultures of Asia. Bangkok: UNESCO.

Vakili-Ardebili, A. (2007). Complexity of value creation in sustainable building design (SBD). Journal of Green Building, 2(4), 171e181.

Whimster, R. (2008). Inventing the future. Conservation Bulletin, Spring(57), $20 \mathrm{e} 25$.

Wilson, A., \& Ward, A. (2009). Design for adaptation: living in a climate changing world. [Online], Available:http://www.buildinggreen.com/auth/article.cfm/2009/8/28/Designfor-addaptationliving viewed December 102009.

Yin, R. K. (2009). Case study research: Design and methods. SAGE.

Yudelson, J. (2010). Greening existing buildings. USA: McGraw Hill Companies, Inc.

Zeiler, W., Quanjel, E., Velden, J., \& Wortel, W. (2010). Flexible design process innovation: Integral building design method. paper presented to Building a Better World: CIB World Congress 2010. United Kingdom: The Lowry, Salford Quays.

Zushi, K. (2005). Potential residential buildings for adaptive reuse-Cincinnati's CBD. In Potential residential buildings for adaptive reuse-Cincinnati's CBD. Unpublished Master, University of Cincinnati. 